\title{
Perspective \\ Wastewater Refinery: Producing Multiple Valuable Outputs from Wastewater
}

\author{
Sigrid Kusch-Brandt 1,2,*(D) and Mohammad A. T. Alsheyab ${ }^{3,4}$ \\ 1 Water and Environmental Engineering Group, University of Southampton, Southampton SO16 7QF, UK \\ 2 Faculty of Mathematics, Natural Sciences and Management, Ulm University of Applied Sciences, \\ 89075 Ulm, Germany \\ 3 Ministry of Development Planning and Statistics, Doha 1855, Qatar; malsheyyab@gmail.com \\ 4 Department of Chemical Engineering, Qatar University, Doha 2713, Qatar \\ * Correspondence: mail@sigrid-kusch.eu
}

Citation: Kusch-Brandt, S.; Alsheyab, M.A.T. Wastewater Refinery: Producing Multiple Valuable Outputs from Wastewater. J 2021, 4, 51-61. https://doi.org/10.3390/j4010004

Academic Editors: Jimmy C. M. Kao and Jong Seong Khim

Received: 1 February 2021

Accepted: 24 February 2021

Published: 27 February 2021

Publisher's Note: MDPI stays neutral with regard to jurisdictional claims in published maps and institutional affiliations.

Copyright: () 2021 by the authors. Licensee MDPI, Basel, Switzerland. This article is an open access article distributed under the terms and conditions of the Creative Commons Attribution (CC BY) license (https:// creativecommons.org/licenses/by/ $4.0 /)$.
Abstract: A wastewater refinery is a multifunctional solution that combines different technologies and processing schemes to recover a spectrum of valuable materials from municipal or industrial wastewater. The concept of wastewater refinery introduces a new perspective on wastewater treatment and management. It aims at making the most of wastewater constituents by co-producing different worthful outputs, such as water, energy, nitrogen, sulfide, and phosphorous. This can turn the treatment of wastewater from a major cost into a source of profit. The wastewater refinery approach is well aligned with the concept of the circular economy. A case study on Qatar's wastewater revealed the potential recovery of significant quantities of valuable resources embodied in the country's wastewater. Valorization of organic constituents and the recovery of nitrogen, phosphorus, and sulfide should be given priority. To facilitate the adoption of the wastewater refinery concept, research is required to explore technical and economic bottlenecks.

Keywords: wastewater refinery; wastewater recycling; resource recovery; circular economy; resource efficiency; mass flow analysis; nutrients

\section{Introduction}

As a result of the increasing pace of industrialization, urbanization, and agricultural activities during the last decades, water pollution and water scarcity have become critical issues of our modern societies [1]. To achieve a transition towards more sustainable development, new concepts of wastewater treatment are needed [2-4]. Therefore, sound management of wastewater unfolds to be an issue of even higher priority. The Agenda 2030 for Sustainable Development of the United Nations, Sustainable Development Goal 6 (SDG 6: Clean Water and Sanitation) specifies that countries should halve the proportion of untreated wastewater and substantially increase recycling and safe reuse by 2030 . Reaching SDG 6 is embedded in the achievement of all the other sixteen SDGs of the Agenda 2030 [5].

Quantity and quality of wastewater depend on many factors, such as human behavior and lifestyle, standards of living and economic development stage of a society, prevailing water management systems, including the design of sewer systems, and regulatory frameworks [6,7]. Wastewater contains components of environmental and human health concern [8], considered as pollutants, such as oxygen-depleting ammonia, organic loading, synthetic organic chemicals, and more recently, microplastics [9]. To reduce environmental and human health risks, the prevailing paradigm of wastewater management aims at effectively decontaminating the wastewater flow by removing pollutants through the application of different processes. The performance levels of installed wastewater treatment systems strongly vary globally and regionally, with the economic development stage of countries being a relevant factor [10]. 
The proportion of the global population who still lack even the basic sanitation service was estimated at $27 \%$ in 2017 [11]. In many developing countries, significant quantities of wastewater continue to be discharged without treatment to natural water bodies. Rapid urbanization and industrialization frequently undermine progress towards better sanitation despite efforts of constructing more wastewater treatment facilities [12]. In contrast, in developed countries, more than $95 \%$ of the population is connected to a wastewater treatment scheme, usually a WWTP (wastewater treatment plant) [13]. Stateof-the-art wastewater purification systems today employ manifold technologies based on physical, biological, chemical processes, or their combination [8], which consume energy and chemicals. Wastewater treatment accounts for 3\% of the total global energy demand, and it is responsible for more than half of the greenhouse gas emissions of the water industry [14]. WWTPs are highly resource-intensive facilities [13].

At the same time, wastewater itself represents a potential resource because its constituents can be recovered as secondary raw materials. As an example, nutrients, such as phosphorus and nitrogen, if recovered from the wastewater flow, can serve as input materials for agricultural fertilizer production [15], while otherwise, they risk causing eutrophication of water bodies. Wastewater treatment and recovery of valuable components do not only contribute to reducing adverse environmental impacts associated with human settlements and industrial production sites but also represent viable strategies to alleviate water scarcity and use natural resources more effectively.

Wastewater recycling is increasingly seen as an integral part of water demand management [16]. The recovery of valuable components, such as phosphorus, is becoming more and more applied in practice [17], however, the economically viable recovery of nutrients from wastewater remains challenging, especially in developing countries [18].

While resource recovery from wastewater is not a new approach, the focus so far has mainly been on the recovery of a single material of interest or on increasing the effectiveness and efficiency of existing technical solutions. A more holistic framework to look at wastewater as a versatile resource, including as a strategic element to sustainably manage freshwater, is missing. Freshwater, like biomass, represents a renewable resource with a risk of overexploitation if not carefully managed (i.e., if the sustainable yield is exceeded), and thus freshwater and biomass both are conditionally renewable resources. To reduce the risk of undermining the regenerative capacity of such conditionally renewable resources, it is essential to make the best possible use of each unit of the resource. For biomass, this challenge of using each unit of the resource with highest productivity has been captured by introducing the concept of biorefinery, which aims at processing the different constituents of biomass individually in order to produce different valuable outputs [19]. Like biomass, wastewater contains different components which could be valorized at a high value by applying a refinery approach. This novel perspective of wastewater refinery is elaborated in this work. The concept of wastewater refinery comes as an advanced approach of integrative and multifunctional wastewater management, targeting the recovery of different valuable wastewater components under a holistic optimization perspective. The emerging concept of wastewater refinery shares some conceptual elements with other refinery approaches, such as petroleum refinery and biorefinery, but it also has unique features because it is tailored to make the best possible use of wastewater under a circular economy approach.

The goal of this paper is to present the concept of wastewater refinery with its main approach, key features, and benefits. In doing so, this work aims at triggering a new scientific discussion on how to sustainably manage wastewater, and thus this work also aims at paving the way to identify new and optimum wastewater treatment technologies. To illustrate a potential application in practice, the paper builds upon our previously published case study ('Potential recovery assessment of the embodied resources in Qatar's wastewater') in the journal Sustainability [20], where an analytical assessment was conducted into the potential recovery of resources from wastewater in the state of Qatar. The concept of wastewater refinery as such was only briefly introduced but was not discussed in detail. An 
initial introduction of wastewater refinery was made available by an entry published on the MDPI Encyclopedia Platform, titled 'Wastewater Refinery' [21], however, due to the nature of the encyclopedia entry, the information available there represents a general overview only. A significantly extended journal version is presented here upon an invitation of the editor of the J journal to bring the concept to the attention of a broader audience.

\section{The Concept of Wastewater Refinery}

\subsection{Wastewater Refinery: Interrelation with Petroleum Refinery and Biorefinery}

The concept of wastewater refinery $[20,21]$ is inspired by the concepts of petroleum refinery (also referred to as petrochemical refinery, or simply oil refinery) and biorefinery. In all these refinery approaches, different technologies and processes are combined together (usually in one factory or a processing network) to supply a variety of marketable products in parallel, thus making the most of the components embodied in the influent to be processed [22]. The input of a petroleum refinery is crude mineral oil, while the input of a biorefinery is biomass, either biomass purposely grown and harvested for this purpose or organic residues, such as biowaste from households, food waste, or agricultural residues. In the case of wastewater refinery, the input is wastewater originating from households or industry.

A petroleum refinery is a standard industrial facility to transform crude mineral oil into marketable intermediate or final products, such as diesel fuel, gasoline, heating oil, kerosene, and feedstock for the petrochemical industry like ethylene and propylene. Petroleum refineries are tightly coupled to the widespread usage of fossil resources and, therefore, have a long history.

The biorefinery approach is an emerging concept that has been under research and development over the last decades, and it continues to be further evolving [23]. Similar to a petroleum refinery, biorefinery is a multifunctional solution that uses different methods and technologies widely in parallel to produce a spectrum of valuable outputs. This acknowledges biomass as a diverse resource that contains a variety of components that can all be used in well-tailored schemes to generate the highest benefit from each unit of biomass. Typical products of a biorefinery are bio-based chemicals, biofuels, bioenergy, and food. Biotechnological processes, employing microorganisms to achieve the envisaged goal, are often used in combination with chemical or thermochemical processes. Implementation of biorefinery schemes is seen as a solution to make the best possible use of the limited biomass resources, and it is a step forward to pave the way for a bio-based circular economy $[24,25]$.

Wastewater is composed of a variety of components as well, including water, organic compounds, inorganic materials, sulfide, heavy metals, and nutrients, such as phosphorous and nitrogen, all of which can be valorized after recovery. The field of wastewater treatment processes applied in practice or under ongoing research and development is vast $[26,27]$. A review of the methods available to recover and valorize individual wastewater components is not within the scope of this article and is available elsewhere $[20,28,29]$. This article specifically focuses on the conceptual idea of wastewater refinery. A refinery approach for wastewater targets the holistic recovery of the individual components for their valorization by combining different technologies in an integrated concept. In analogy to petroleum refinery and biorefinery, co-production represents a key encapsulated feature of a wastewater refinery, i.e., the joint delivery of several valuable products based on using a diversified processing scheme at one site or within a structurally coupled network of specialized facilities.

Table 1 shows a comparison of the main characteristics of wastewater refineries, biorefineries, and petroleum refineries. It becomes evident that all three refinery concepts couple different material and/or energetic utilization pathways to produce a set of different marketable outputs. It further becomes clear that a wastewater refinery focuses on the recovery of diverse components contained in wastewater (no matter whether the components are 
organic or inorganic), while a biorefinery focuses on organic materials (biomass) and a petroleum refinery on fossil resources.

Table 1. Comparison between petroleum refinery, biorefinery, and wastewater refinery.

\begin{tabular}{|c|c|c|c|}
\hline & Petroleum Refinery & Biorefinery & Wastewater Refinery \\
\hline Raw material & Mineral oil & $\begin{array}{l}\text { Biomass from } \\
\text { agricultural } \\
\text { production or forests, } \\
\text { biowastes or other } \\
\text { organic residues }\end{array}$ & $\begin{array}{l}\text { Wastewater from } \\
\text { households or } \\
\text { industry }\end{array}$ \\
\hline Processing & $\begin{array}{l}\text { Thermochemical } \\
\text { processes and } \\
\text { catalytic applications }\end{array}$ & $\begin{array}{l}\text { Biotechnological } \\
\text { processes in } \\
\text { combination with } \\
\text { chemical processes, } \\
\text { physical processes, } \\
\text { thermochemical }^{1} \\
\text { processes }^{1}\end{array}$ & $\begin{array}{l}\text { Chemical processes, } \\
\text { physical processes, } \\
\text { thermochemical } \\
\text { processes, } \\
\text { biotechnological } \\
\text { processes }^{1}\end{array}$ \\
\hline Product outputs & $\begin{array}{l}\text { Fossil-based products, } \\
\text { such as vehicle fuels, } \\
\text { heating oil, bulk } \\
\text { materials, chemicals }\end{array}$ & $\begin{array}{l}\text { Bio-based products } \\
\text { (organic materials), } \\
\text { such as bulk } \\
\text { materials, chemicals } \\
\text { and pharmaceuticals, } \\
\text { food, fodder, fuels }{ }^{2}\end{array}$ & $\begin{array}{l}\text { Wastewater- } \\
\text { originating products } \\
\text { (organic or inorganic), } \\
\text { such as nutrients, } \\
\text { chemicals, organic } \\
\text { materials, fuels, } \\
\text { freshwater }{ }^{2}\end{array}$ \\
\hline
\end{tabular}

$\overline{{ }^{1} \text { Not all of these are necessarily applied in each refinery; }{ }^{2} \text { Not all product types are necessarily provided by each }}$ refinery, but each refinery delivers a spectrum of valuable outputs, typically combining different material and energetic utilization pathways.

\subsection{Biorefinery Application for Wastewater}

Application of a biorefinery approach to wastewater, i.e., the advanced recovery of bio-based materials from wastewater through biotechnological processes, has been proposed by various researchers. Delrue et al. [30] studied the performance of microalgae to remediate wastewater in a biorefinery concept, targeting the energy market by producing biofuels. Microalgae biorefineries based on wastewater have become a prominent research area [31-33]. Especially the production of biopolymers from wastewater by microalgae is currently receiving great attention [34]. The cultivation of aquatic weeds on wastewater, such as duckweed, with the subsequent processing in biorefinery schemes to obtain multiple outputs, including ethanol, methane, and volatile fatty acids, has also been studied $[35,36]$. Other researchers have focused on individual elements that could be included when conceptualizing a biorefinery, such as the recovery of lipids from wastewater for the production of biodiesel [37] or the cultivation of cellulase on domestic wastewater [38]. Wastewater-based biorefinery schemes have been referred to as "wastewater biorefinery" [39,40].

\subsection{Key Features of a Wastewater Refinery}

While the wastewater biorefinery (discussed above) focuses selectively on a subset of wastewater components, namely the biogenic components or those which can be valorized through biotechnological processing, the wastewater refinery concept holistically takes into consideration that wastewater is composed of water, inorganic and organic (biogenic) components, and it focuses on the recovery of all types of materials which are present. Therefore, the wastewater refinery includes physical, chemical, thermochemical, and biological processes, and the combination of the processes serves to recover the target set of valuable components. Physical processes usually use screens and filters to remove solids, biological processes use microorganisms, chemical processes exploit chemical reactions between components, and thermochemical processes make use of chemical reactions at an elevated temperature. 
Integrated processing of wastewater with the aim of co-producing different valuable outputs, including bulk materials, fine chemicals, and energy, opens opportunities for synergies to achieve efficient and effective wastewater valorization. Such a concept that aims at recovering and recycling the constituents embodied in wastewater would contribute to the implementation of circular economy schemes as well as to turning the treatment of wastewater from being a major cost into a source of profit. Clearly, wastewater refineries focus on the recovery of marketable outputs that have greater potential to deliver economic and environmental benefits than the prevailing wastewater management systems, which focus mainly on reducing pollution loads. This paradigmatic change represents a turning point in wastewater management strategies.

The design of a wastewater refinery would require a detailed assessment of both the technical and the economic feasibility of the integrated wastewater treatment processes and must be tailored based on the wastewater characteristics and composition. The following section presents key findings of a case study on wastewater in the country of Qatar.

\section{Example of a Wastewater Refinery Approach: Case Study on Qatar's Wastewater}

A case study based on material flow analysis (elaborated with STAN software [41]) was conducted on the municipal wastewater in Qatar to show the potential recovery of valuable constituents embodied in wastewater. The material flow analysis established a quantitative assessment of the following components in Qatari wastewater: Solids (dissolved, suspended, and volatile), COD (Chemical Oxygen Demand), biodegradable constituents as BOD (Biochemical Oxygen Demand) and 'Oil and Grease', nutrients (phosphorous and nitrogen), alkalinity, chloride, and sulfide. To estimate the potential recovery of components, only state-of-the-art recovery schemes which are in common use in practice were considered in the study, while emerging recycling technologies were not included. Thus, the study focused on the recovery potential of wastewater components when using well-established equipment (standard technical equipment), with low risk for failure or uncertainty. The full case study was presented in an earlier publication [20].

Results of the case study revealed that there is a significant potential to recover several valuable components from Qatar's wastewater.

When analyzing the nutrient contents, the findings showed that nitrogen and phosphorous contained in Qatari wastewater alone could have a market value of more than US $\$ 5$ million per year. The recoverable contents of phosphorous and nitrogen are shown in Figure 1 . The monetary value of nitrogen and phosphorous was estimated based on the low end of price information for fertilizer constituents [42].

Another promising valorization pathway is the recovery of biogas via anaerobic digestion of organic wastewater constituents (for the mass flow analysis, please see the earlier publication [20]). The potential gas generation, based on the organic content of the Qatari wastewater, was estimated to amount to around 27 million $\mathrm{m}^{3}$ of methane (equivalent to energy content of more than $270 \mathrm{GWh}$ ) per year. Therefore, the inclusion of anaerobic digestion as one key process within a wastewater refinery could be an attractive choice. This would integrate a component commonly used in biorefinery schemes into the wastewater refinery. The integration of emerging and potentially more advanced recovery strategies currently researched within biorefinery approaches, such as the production of biopolymers [43,44], was not considered in the case study for Qatar but could also be an attractive solution to valorize organic constituents present in wastewater.

Furthermore, the case study showed that significant quantities of sulfide are embodied in Qatar's wastewater, with a potential to be recovered using standard technical solutions. Other recoverable valuable components, such as chloride or oil and grease, are present in significant quantities and could be included in more complex wastewater recycling schemes. 


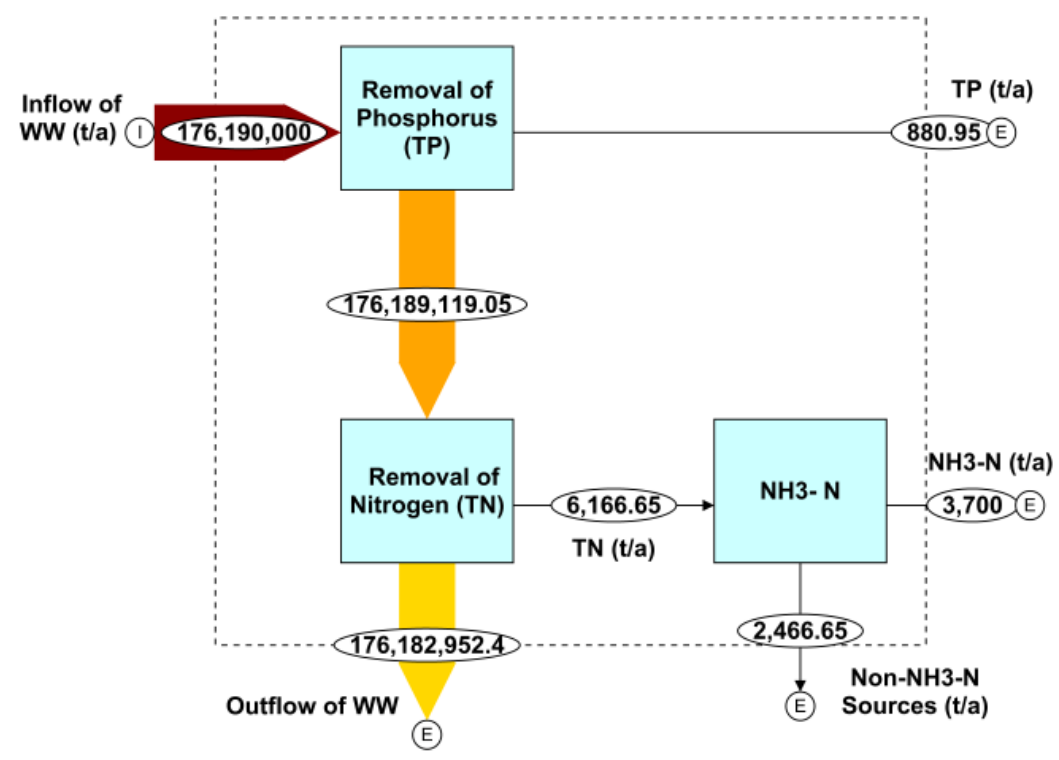

Figure 1. Mass flow analysis of nutrients (phosphorus, nitrogen) in Qatari wastewater, all flows in metric tons per year (WW: Wastewater, TP: Total phosphorous, TN: Total nitrogen, NH3-N: Ammonia nitrogen, I: Inflow; E: Export/output) [20].

The case study on Qatar reveals that the benefits of integrated wastewater processing are not limited to recovery and recycling of components that represent the pollution load of wastewater flows, but also include reuse of water itself after wastewater treatment. Qatar suffers from physical water scarcity where valorization of treated wastewater has been identified as an option to alleviate water stress in the country [45]. Treated wastewater could be used for irrigation purposes in agriculture, to replenish groundwater reservoirs, or for specific applications in households or industry where the required water quality complies with implementing cascaded water usage schemes, i.e., where water in downstream applications has already served for other applications but is still fit for the specific purpose, such as for toilet flushing.

Interestingly, relatively high alkalinity was found in Qatari wastewater. This suggests that constituents not studied individually in the work were contained in relevant quantities in the wastewater, and thus the set of valuable components might be more diverse, potentially including recoverable components, such as potassium, sodium, calcium, and magnesium.

\section{Discussion}

\subsection{Discussion of Case Study Findings}

The case study on the Qatari wastewater (Section 3) illustrated the high potential of implementing a wastewater refinery. The focus of the study was to assess and quantify the recoverable components. The work did not investigate the best available techniques that could be transferred to Qatar to be implemented in an economically viable way. This requires further research to identify the best technical solutions and their economic performance under an existing situation in practice. A conceptualized process of wastewater refinery is illustrated in Figure 2, based on considering nitrogen $(\mathrm{N})$, phosphorous $(\mathrm{P})$, organic carbon, and water itself, i.e., a scenario found particularly promising in the context of the research for Qatar (see above). In this wastewater refinery, anaerobic digestion is applied to convert the organic portion into methane, which can be used to produce electricity, while digestate from the anaerobic digestion can be recycled as a soil improver. Ion exchangers are employed to separate phosphorous and nitrogen in order to produce fertilizer for agricultural applications. Water flows are generated at different stages of the process with different qualities to serve for various applications (irrigation, industrial and service water, drinking water). 


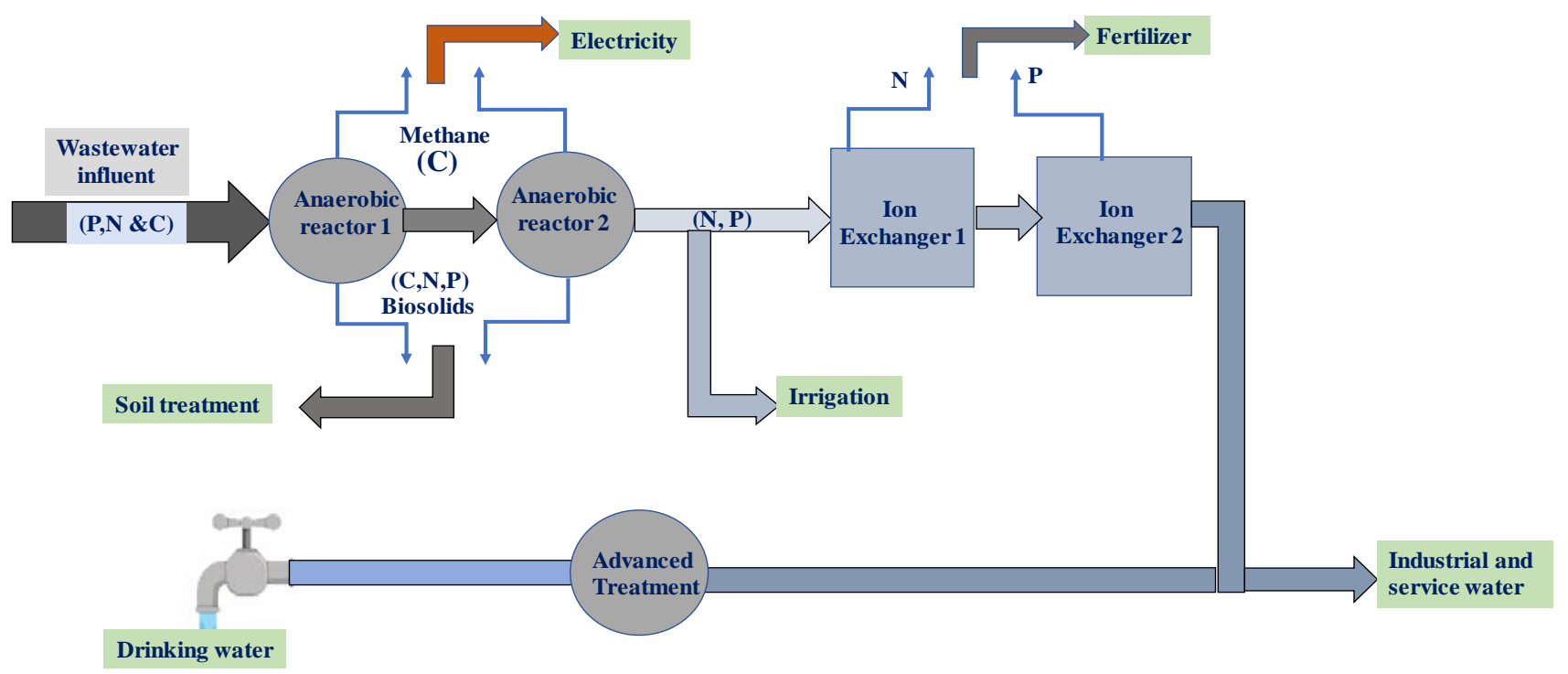

Figure 2. Process scheme to recover phosphorous $(\mathrm{P})$, nitrogen $(\mathrm{N})$, and organic material (organic carbon $\mathrm{C}$ ) from wastewater.

This example introduces a promising vision for the proposed concept of a multifunctional wastewater management strategy. The results of the presented case study pave the way for the implementation of wastewater refineries for the sound management of Qatari wastewater and for wastewater elsewhere.

\subsection{Implementation of a Wastewater Refinery: Factors to Be Considered}

To transfer the concept of wastewater refinery to other regions or cases of applications, a number of key factors should be considered, as outlined below.

The specific wastewater treatment technologies and their combination need to be carefully evaluated and adapted to the local situation, taking into consideration the economic, geographical, social, and technical parameters [26,27]. A very broad set of wastewater treatment options are found in practice, and a one-size-fits-all solution is not to be expected for the advanced recovery of nutrients from wastewater [26]. High variations in the composition of wastewater streams and case-specific economic viabilities of solutions make it essential to design a wastewater treatment scheme for each context individually.

In contrast to conventional wastewater treatment, where the design is mainly based on wastewater composition, the wastewater refinery approach takes into consideration the composition of wastewater and the targeted marketable outputs, especially the recovered secondary resources. Not only the technical design of the wastewater scheme is more complex in a wastewater refinery concept, but also the economic viability assessment. Market dynamics of resource types might be difficult to be predicted, but the market situation for secondary resources recovered by circular economy applications must necessarily be factored in to allow sound decision-making. The design and implementation of a wastewater refinery require more than technical expertise. Engineering aspects, economics, and engagement with stakeholders are of equal importance.

Water demand is expected to grow worldwide by $55 \%$ by 2050 [46]. Already today, only about $15 \%$ of the global population lives with relative water abundance, while most people are affected by at least latent pressure of potential water scarcity [47]. Many countries around the world, especially in Asia and Africa, will be facing aggravating freshwater scarcity in the coming decades, where the increase in water recycling will be essential [48]. Therefore, the recovery of purified water for usage in irrigation, groundwater recharge, or other applications will very often deserve high focus in addition to the recovery of nutrients or other marketable outputs of a wastewater refinery. 


\subsection{Relevance of the Wastewater Refinery Concept}

Wastewater refinery as a new paradigm is a prospective framework to provide a holistic conceptual umbrella for ideas and efforts to look at wastewater as a valuable resource. This can overcome the currently fragmented approach of research and practice in the field of wastewater management, where the focus is on single technologies, single processes, or single components contained in wastewater, often under the lens of effectively removing pollutants. Instead, the refinery perspective comprehensively captures the value of looking at the diversity of constituents present in wastewater primarily under a resourcerecovery lens, i.e., to effectively take advantage of the variety of wastewater components.

Aiming for the fullest possible use of the components, the wastewater refinery approach shares similarity to the approach of looking at biomass from a biorefinery perspective instead of a single selected biomass treatment scheme. The wastewater refinery can benefit from the high attention recently given to the biorefinery concept in research and development because the refinery concept has been widely acknowledged as holding higher potential for environmental and economic benefits compared to reference systems. This is transferable from biorefinery to wastewater refinery. In particular, the refinery approach illustrates that a spectrum of marketable outputs can significantly alter the economic viability of processing a waste material or a residue, thus changing a waste or residue from being a cost factor into a source of economic profit [49-51]. Wastewater refinery represents a novel application of the refinery concept, however, the successful adoption of the biorefinery concept, which the last decade has witnessed, and the wide acknowledgment of its benefits can facilitate the adoption of this new type of refinery based on wastewater as the resource.

The concept of wastewater refinery is equally important for research, education, and practice. Learning from the biorefinery context suggests that such a complex idea benefits from first being adopted and advanced by researchers [52,53] in order to explore potential bottlenecks and most favorable arrangements, including under sustainability criteria, and thus to create a more mature understanding of a successful implementation.

While the implementation of wastewater refineries represents a promising pathway to make more efficient use of natural resources, to implement more circular economies, and to alleviate water scarcity, the reduction of water usage and thus prevention of wastewater generation should be given the highest priority. Wastage of water violates the basic idea of sustainable development because it jeopardizes the current and future availability of the most essential resource of life on earth. Water wastage must come to an end. Where the reduction of water usage is not feasible, the advanced and holistic wastewater management approach encapsulated in the concept of wastewater refinery, i.e., co-recovery of water of adequate quality along with other valuable constituents, ensures that the conditionally renewable resource freshwater is respected as much as possible.

\subsection{Research Needs}

Wastewater refinery is an emerging concept. To unlock its potential, research is required to identify and explore the technical and economic bottlenecks. Technical limits of operating different processes widely in parallel must be comprehensively framed. Different technically feasible wastewater refinery product portfolios should be analyzed regarding the quality of recovered components and the potential barriers to market success. Case studies on different wastewaters are required to create a broader knowledge base. Wastewater refinery pilot projects can support the adoption of the concept in practice, and they can support the popularization of the concept as such by involving stakeholders from industry, administration, and policy-making, including local and regional decision-makers.

Research efforts should also be spent to better understand the factors that support or undermine the adoption of innovative and resource-oriented concepts, such as wastewater refinery, in regions where water and wastewater management are currently underdeveloped. As an example, Lufingo [54] observed that a too high diversity among water quality laboratories in Tanzania negatively affected the performance of the public water supply and sanitation authorities in the country. 
How to strategically integrate the perspective of wastewater refinery into the existing landscape of wastewater management approaches is another important question. Engaging multi-stakeholders from academia and industry is essential to advance towards considering wastewater primarily as a multifaceted resource and to put the concept of wastewater refinery into practice.

\section{Conclusions}

A wastewater refinery aims at joint production of different marketable products based on wastewater as the resource, using advanced integrated processing schemes at one single location or within a network of facilities. This approach takes into consideration that wastewater is composed of a variety of different components that can be recovered and valorized through appropriate technologies and processing schemes. Under such an advanced conceptual framework, wastewater management is no longer primarily targeting environmentally clean wastewater, but instead, it aims at co-generating valueadded outputs based on recovering the embodied organics, nutrients, chemicals, and other components.

The conceptual idea of wastewater refinery was demonstrated by the case study on Qatar using the material flow analysis of different constituents embodied in wastewater. The case study on Qatari wastewater confirmed the availability of significant quantities of valuable components that could be potentially recovered and used for different purposes. This includes the reuse of treated wastewater for irrigation, groundwater replenishment, or cascaded water application schemes, such as toilet flushing. Furthermore, the implementation of an integrated wastewater refinery for Qatari wastewater is highly promising for the recovery of nutrients, such as phosphorous and nitrogen, to be used as secondary raw materials in the production of agricultural fertilizers. The recovery of sulfide as a secondary raw material for the chemical industry and an energetic valorization of organic constituents via anaerobic digestion with biogas production are further promising.

The potential benefits that can be obtained through wastewater refinery schemes should not distract the attention of policymakers from the top priority of wastewater prevention, i.e., the reduction of water consumption must be given the highest urgency when defining programs for sound water management. Nevertheless, the implementation of wastewater refineries, focused on the recovery of a set of valuable materials, is an effective pathway in the transition from a linear economy to a circular economy and more sustainable management of environmental resources. This is well aligned with achieving the Sustainable Development Goals of the United Nations.

Author Contributions: Conceptualization, S.K.-B. and M.A.T.A.; investigation, M.A.T.A. and S.K.-B.; writing—original draft preparation, S.K.-B. and M.A.T.A.; writing—review and editing, S.K.-B. and M.A.T.A. Both authors have read and agreed to the published version of the manuscript.

Funding: This research received no external funding.

Institutional Review Board Statement: Not applicable.

Informed Consent Statement: Not applicable.

Data Availability Statement: Not applicable.

Conflicts of Interest: The authors declare no conflict of interest.

\section{References}

1. Fierascu, R.C.; Brazdis, R.I.; Fierascu, I.; Baroi, A.M.; Fistos, T.; Avramescu, S.M. Green technologies for wastewater depollution. Proceedings 2020, 57, 30. [CrossRef]

2. Zarei, M. Wastewater resources management for energy recovery from circular economy perspective. Water Energy Nexus 2020, 3, 170-185. [CrossRef]

3. Herrera Melián, J.A. Sustainable wastewater treatment systems (2018-2019). Sustainability 2020, 12, 1940. [CrossRef]

4. Jarvis, P. Environmental technology for the sustainable development goals (SDGs). Environ. Technol. 2020, 41, 2155-2156. [CrossRef] [PubMed] 
5. Ho, L.; Alonso, A.; Forio, M.A.E.; Vanclooster, M.; Goethals, P.L.M. Water research in support of the Sustainable Development Goal 6: A case study in Belgium. J. Clean. Prod. 2020, 277, 124082. [CrossRef]

6. Tomar, M. Quality Assessment of Water and Wastewater; Lewis: Boca Raton, FL, USA, 1999; ISBN 9781566703826.

7. Almeida, M.C.; Butler, D.; Friedler, E. At-source domestic wastewater quality. Urban Water 1999, 1, 49-55. [CrossRef]

8. Yenkie, K.M. Integrating the three E's in wastewater treatment: Efficient design, economic viability, and environmental sustainability. Curr. Opin. Chem. Eng. 2019, 26, 131-138. [CrossRef]

9. Turan, N.B.; Erkan, H.S.; Engin, G.O. Microplastics in wastewater treatment plants: Occurrence, fate and identification. Process Saf. Environ. Prot. 2021, 146, 77-84. [CrossRef]

10. Malik, O.A.; Hsu, A.; Johnson, L.A.; De Sherbinin, A. A global indicator of wastewater treatment to inform the Sustainable Development Goals (SDGs). Environ. Sci. Policy 2015, 48, 172-185. [CrossRef]

11. WHO (World Health Organization). Progress on Household Drinking Water, Sanitation and Hygiene 2000-2017: Special Focus on Inequalities; World Health Organization: Geneva, Switzerland, 2019; Available online: https://www.who.int/water_sanitation_ health/publications/jmp-report-2019/en (accessed on 12 February 2021).

12. UN-Water Decade Programme on Advocacy and Communication (UN-Water). Water Quality and Sanitation. Media Brief. 2010. Available online: https://www.un.org/waterforlifedecade/swm_cities_zaragoza_2010/pdf/01_water_quality_and_sanitation. pdf (accessed on 12 February 2021).

13. Mocholi-Arce, M.; Gómez, T.; Molinos-Senante, M.; Sala-Garrido, R.; Caballero, R. Evaluating the eco-efficiency of wastewater treatment plants: Comparison of optimistic and pessimistic approaches. Sustainability 2020, 12, 10580. [CrossRef]

14. Nakkasunchi, S.; Hewitt, N.J.; Zoppi, C.; Brandoni, C. A review of energy optimization modelling tools for the decarbonisation of wastewater treatment plants. J. Clean. Prod. 2021, 279, 123811. [CrossRef]

15. Ye, Y.; Ngo, H.H.; Guo, W.; Chang, S.W.; Nguyen, D.D.; Zhang, X.; Zhang, J.; Liang, S. Nutrient recovery from wastewater: From technology to economy. Bioresour. Technol. Rep. 2020, 11, 100425. [CrossRef]

16. Durán-Sánchez, A.; Álvarez-García, J.; González-Vázquez, E.; Del Río-Rama, M.D.L.C. Wastewater management: Bibliometric analysis of scientific literature. Water 2020, 12, 2963. [CrossRef]

17. Diaz-Elsayed, N.; Rezaei, N.; Ndiaye, A.; Zhang, Q. Trends in the environmental and economic sustainability of wastewater-based resource recovery: A review. J. Clean. Prod. 2020, 265, 121598. [CrossRef]

18. Chrispim, M.C.; Scholz, M.; Nolasco, M.A. Phosphorus recovery from municipal wastewater treatment: Critical review of challenges and opportunities for developing countries. J. Environ. Manag. 2019, 248, 109268. [CrossRef] [PubMed]

19. Kumar, B.; Verma, P. Biomass-based biorefineries: An important architype towards a circular economy. Fuel 2021, 288, 119622 [CrossRef]

20. Alsheyab, M.A.T.; Kusch-Brandt, S. Potential recovery assessment of the embodied resources in Qatar's wastewater. Sustainability 2018, 10, 3055. [CrossRef]

21. Kusch-Brandt, S.; Alsheyab, M.A.T. Wastewater Refinery (A Wastewater Refinery to Deliver Added Value from Wastewater). Entry 231 to the MDPI Encyclopedia Platform. 2019. Available online: https:/ / encyclopedia.pub/231 (accessed on 20 December 2020).

22. Kohli, K.; Prajapati, R.; Sharma, B.K. Bio-based chemicals from renewable biomass for integrated biorefineries. Energies 2019, 12, 233. [CrossRef]

23. Cherubini, F. The biorefinery concept: Using biomass instead of oil for producing energy and chemicals. Energy Convers. Manag. 2010, 51, 1412-1421. [CrossRef]

24. Ubando, A.T.; Felix, C.B.; Chen, W.-H. Biorefineries in circular bioeconomy: A comprehensive review. Bioresour. Technol. 2020, 299, 122585. [CrossRef]

25. Attard, T.M.; Clark, J.H.; McElroy, C.R. Recent developments in key biorefinery areas. Curr. Opin. Green Sustain. Chem. 2020, 21, 64-74. [CrossRef]

26. Kyzas, G.Z.; Matis, K.A. Wastewater treatment processes: Part I. Processes 2020, 8, 334. [CrossRef]

27. Goffi, A.S.; Trojan, F.; De Lima, J.D.; Lizot, M.; Thesari, S.S. Economic feasibility for selecting wastewater treatment systems. Water Sci. Technol. 2018, 78, 2518-2531. [CrossRef] [PubMed]

28. Shaddel, S.; Bakhtiary-Davijany, H.; Kabbe, C.; Dadgar, F.; Østerhus, S.W. Sustainable sewage sludge management: From current practices to emerging nutrient recovery technologies. Sustainability 2019, 11, 3435. [CrossRef]

29. Kehrein, P.; Van Loosdrecht, M.; Osseweijer, P.; Garfí, M.; Dewulf, J.; Posada, J. A critical review of resource recovery from municipal wastewater treatment plants-market supply potentials, technologies and bottlenecks. Environ. Sci. Water Res. Technol. 2020, 6, 877-910. [CrossRef]

30. Delrue, F.; Álvarez-Díaz, P.D.; Fon-Sing, S.; Fleury, G.; Sassi, J.-F. The environmental biorefinery: Using microalgae to remediate wastewater, a win-win paradigm. Energies 2016, 9, 132. [CrossRef]

31. Goswami, R.K.; Mehariya, S.; Verma, P.; Lavecchia, R.; Zuorro, A. Microalgae-based biorefineries for sustainable resource recovery from wastewater. J. Water Process Eng. 2020, 101747, in press. [CrossRef]

32. Bhatia, S.K.; Mehariya, S.; Bhatia, R.K.; Kumar, M.; Pugazhendhi, A.; Awasthi, M.K.; Atabani, A.E.; Kumar, G.; Kim, W.; Seo, S.-O.; et al. Wastewater based microalgal biorefinery for bioenergy production: Progress and challenges. Sci. Total Environ. 2021, 751, 141599. [CrossRef] 
33. Javed, F.; Aslam, M.; Rashid, N.; Shamair, Z.; Khan, A.L.; Yasin, M.; Fazal, T.; Hafeez, A.; Rehman, F.; Rehman, M.S.U.; et al. Microalgae-based biofuels, resource recovery and wastewater treatment: A pathway towards sustainable biorefinery. Fuel 2019, 255, 115826. [CrossRef]

34. Lutzu, G.A.; Ciurli, A.; Chiellini, C.; Di Caprio, F.; Concas, A.; Dunford, N.T. Latest developments in wastewater treatment and biopolymer production by microalgae. J. Environ. Chem. Eng. 2021, 9, 104926. [CrossRef]

35. Calicioglu, O.; Richard, T.L.; Brennan, R.A. Anaerobic bioprocessing of wastewater-derived duckweed: Maximizing product yields in a biorefinery value cascade. Bioresour. Technol. 2019, 289, 121716. [CrossRef] [PubMed]

36. Kaur, M.; Kumar, M.; Singh, D.; Sachdeva, S.; Puri, S.K. A sustainable biorefinery approach for efficient conversion of aquatic weeds into bioethanol and biomethane. Energy Convers. Manag. 2019, 187, 133-147. [CrossRef]

37. Frkova, Z.; Venditti, S.; Herr, P.; Hansen, J. Assessment of the production of biodiesel from urban wastewater-derived lipids. Resour. Conserv. Recy. 2020, 162, 105044. [CrossRef]

38. Libardi, N.; Soccol, R.C.; De Carvalho, J.C.; Porto De Souza Vandenberghe, L. Simultaneous cellulase production using domestic wastewater and bioprocess effluent treatment-A biorefinery approach. Bioresour. Technol. 2019, 276, 42-50. [CrossRef] [PubMed]

39. Waqas, M.; Rehan, M.; Aburiazaiza, A.S.; Nizami, A.-S. Chapter 17-Wastewater biorefinery based on the microbial electrolysis cell: Opportunities and challenges. In Progress and Recent Trends in Microbial Fuel Cells; Kundu, P.P., Dutta, K., Eds.; Elsevier: Amsterdam, The Netherlands, 2018; pp. 347-374.

40. Pott, R.; Johnstone-Robertson, M.; Verster, B.; Rumjeet, L.; Nkadimeng, L.; Raper, T.; Rademeyer, S.; Harrison, S.T.L. Wastewater biorefineries: Integrating water treatment and value recovery. In The Nexus: Energy, Environment and Climate Change, Green Energy and Technology; Leal Filho, W., Surroop, D., Eds.; Springer: Cham, Switzerland, 2018; pp. 289-302.

41. Cencic, O.; Rechberger, H. Material flow analysis with software STAN. J. Environ. Eng. Manag. 2008, 18, 3-7.

42. FNR (Fachagentur Nachwachsende Rohstoffe). Handreichung Biogasgewinnung und Nutzung, 3rd ed.; FNR: Gülzow, Germany, 2006; ISBN 3-00-014335-5. (In German)

43. Liu, F.; Li, J.; Zhang, X.L. Bioplastic production from wastewater sludge and application. IOP Conf. Ser. Earth Environ. Sci. 2019, 344, 012071. [CrossRef]

44. García, N.A.; Álvarez, F.B.; Sierra, A.L.M. Circular economy in the manufacture of bioplastics: From sewage sludge to plastic bottle. Proceedings 2018, 2, 1425. [CrossRef]

45. Qatar Ministry of Development Planning and Statistics. Water Statistics in the State of Qatar 2015; Qatar Ministry of Development Planning and Statistics: Doha, Qatar, 2017.

46. WWAP (United Nations World Water Assessment Programme). The United Nations World Water Development Report 2016: Water and Jobs; UNESCO: Paris, France, 2016.

47. Vörösmarty, C.J.; Lévêque, C.; Revenga, C. Fresh Water. Chapter 7 in Millennium Ecosystems Assessment, Volume 1 Ecosystems and Human Well-Being: Current State and Trends. 2005. Available online: https:/ /www.millenniumassessment.org/documents/ document.276.aspx.pdf (accessed on 12 February 2021).

48. Nisar, M.B.; Shah, S.A.R.; Tariq, M.O.; Waseem, M. Sustainable wastewater treatment and utilization: A conceptual innovative recycling solution system for water resource recovery. Sustainability 2020, 12, 350. [CrossRef]

49. Orive, M.; Cebrián, M.; Amayra, J.; Zufía, J.; Bald, C. Techno-economic assessment of a biorefinery plant for extracted olive pomace valorization. Process Saf. Environ. Prot. 2021, 147, 924-931. [CrossRef]

50. Clauser, N.M.; Felissia, F.E.; Area, M.C.; Vallejos, M.E. A framework for the design and analysis of integrated multi-product biorefineries from agricultural and forestry wastes. Renew. Sustain. Energy Rev. 2021, 139, 110687. [CrossRef]

51. Sanchis-Sebastia, M.; Gomis-Fons, J.; Galbe, M.; Wallberg, O. Techno-economic evaluation of biorefineries based on low-value feedstocks using the BioSTEAM software: A case study for animal bedding. Processes 2020, 8, 904. [CrossRef]

52. Wenger, J.; Stern, T. Reflection on the research on and implementation of biorefinery systems-A systematic literature review with a focus on feedstock. Biofuel Bioprod. Biorefin. 2019, 13, 1347-1364. [CrossRef]

53. Caldeira, C.; Vlysidis, A.; Fiore, G.; De Laurentiis, V.; Vignali, G.; Sala, S. Sustainability of food waste biorefinery: A review on valorisation pathways, techno-economic constraints, and environmental assessment. Bioresour. Technol. 2020, $312,123575$. [CrossRef] [PubMed]

54. Lufingo, M. Public water supply and sanitation authorities for strategic sustainable domestic water management. A case of Iringa Region in Tanzania. J. Multidiscip. Sci. J. 2019, 2, 29. [CrossRef] 